\title{
PENGEMBANGAN BADAN USAHA MILIK DESA (BUMDes) MELALUI PRODUKSI VIRGIN COCONUT OIL (VCO) DAN TURUNANNYA DI DESA DALANG DAN GADUNG SARI*
}

\author{
I N. Ardika ${ }^{1}$, N. N. Darmiati ${ }^{2}$, dan I N. Sujana ${ }^{3}$ \\ * Skim PKW di Desa Dalang dan Gadung Sari Kecamatan Selemadeg Timur Kabupaten Tabanan
}

\begin{abstract}
ABSTRAK
Kegiatan pengabdian kepada masyarakat ini bertujuan untuk memproduksi virgin coconut oil (VCO) dan turunannya (sabun, lulur scrubb beras, dan hand body lotion) di desa Dalang dan Gadung Sari Kecamatan Selemadeg Timur Kabupaten Tabanan, Bali yang merupakan produk dari BUMDes. Metode yang diterapkan dalam pemberdayaan masyarakat pada kegiatan Program Kemitraan Wilayah (PKW) ini adalah: (1) Koordinasi dan komunikasi secara partisipasif dengan Kelompok Tani yang tergabung dengan BUMDes pembuat VCO untuk merumuskan program mulai dari perencanaan, operasional dan evaluasi; (2) Penyuluhan untuk membangun persepsi dan pemahaman Kelompok Tani mengenai inovasi program yang diterapkan; (3) Bimbingan dan Pelatihan mengenai terapan ipteks yang diaplikasi bagi Kelompok Tani; (4) Pendampingan yaitu pertemuan secara berkala dan berkelanjutan antara pendamping dengan Kelompok Tani sasaran hingga ipteks yang diaplikasikankan dapat dilaksanakan secara tepat. Hasil pengabdian menunjukkan bahwa BUMDes Gadung Sari telah membuat sabun dengan pemasaran mendapat order dari Perusahan Daerah Tabanan (Dharma Santika) sebanyak 80 paket setiap bulan, setiap paket berisi empat buah sabun. Kelompok Wanita Tani Nadi Sari Desa Dalang telah menjual sebanyak 258 botol VCO, 133 lulur scrubb beras, 125 sabun padat transparan dan 84 hand body lotion selama Pekan Kesenian Bali yang berlangsung selama 26 hari.
\end{abstract}

Kata kunci : BUMDes, VCO, sabun, lulur, lotion

\begin{abstract}
This community service activity aims to produce virgin coconut oil (VCO) and its derivatives (soap, scrubb rice, and hand body lotion) in Dalang and Gadung Sari villages, Selemadeg Timur District, Tabanan Regency, Bali which are products of BUMDes. The methods applied in community empowerment in the Regional Partnership Program (PKW) activities are: (1) Participatory coordination and communication with the Farmers Group who are members of the VCO-making BUMDes to formulate programs ranging from planning, operations and evaluation; (2) Counseling to build farmer groups' perceptions and understanding of the program innovations implemented; (3) Guidance and Training concerning the application of science and technology applied to Farmers' Groups; (4) Assistance is a periodic and ongoing meeting between the facilitator and the target Farmers Group until the applied science and technology can be implemented appropriately. The results of dedication showed that the Gadung Sari BUMDes had made soap with marketing getting 80 orders from the Tabanan Regional Company (Dharma Santika) each month, each package containing four soaps. The Nadi Sari Women's Farmer Group Dalang Village has sold 258 bottles of VCO, 133 scrubb rice, 125 transparent solid soaps and 84 hand body lotions during the Pekan Kesenian Bali which lasted for 25 days.
\end{abstract}

\footnotetext{
${ }^{1}$ Dosen Fakultas Peternakan Universitas Udayana, pengajar ardika@unud.ac.id

${ }^{2}$ Dosen Fakulta Pertanian Universitas Udayana, pengajar darmiati@unud.ac.id

${ }^{3}$ Dosen Universitas Dwijendra, pengajarSjn.nym@yahoo.com
} 
Keywords: BUMDes, VCO, soap, scrubb, lotion

\section{PENDAHULUAN}

Mata pencaharian penduduk di Desa Dalang dan Gadung Sari Kecamatan Selemadeg Timur Kabupaten Tabanan didominasi pada sektor pertanian ( $82 \%)$, sektor lain yang menonjol dalam penyerapan tenaga kerja adalah perdagangan (4.\%), sektor industri rumah tangga dan pengolahan ( $2,3 \%)$, sektor jasa $(0,8 \%)$ dan sektor lainnya seperti pegawai negeri, karyawan swata dari berbagai sektor $(1,6 \%)$. Ini berarti bahwa sektor pertanian merupakan bidang startegis sehingga perlu medapatkan prioritas.

Dalam Rencana Pembangunan Jangka Menengah (RPJM) Kabupaten Tabanan tahun 2006-2011 Kecamatan Selemadeg Timur khususnya di wilayah Desa Dalang dan Desa Gadung Sari dikembangkan sebagai kawasan agropolitan. Sementara itu, pada subsektor perkebunan, komoditas yang paling banyak diusahakan adalah kelapa yang mencapai 422 ha dengan produksi mencapai 5.250 ton/tahun. Produksi kelapa yang cukup besar di wilayah ini sebagian besar dijual dalam bentuk kelapa butiran sehingga tidak memberikan keuntungan yang memadai bagi petani. Pengembangan usaha pengolahan kelapa akan dapat membantu meningkatkan pendapatan petani dari subsektor perkebunan. Salah satu yang dapat dilakukan adalah dengan alih teknologi pembuatan minyak $\mathrm{VCO}$ (virgin coconut oil) yang mulai banyak diminati petani karena harganya yang mahal dengan pasar yang cukup luas untuk tujuan ekspor. Kendala yang dihadapi adalah lemahnya penguasaan teknologi petani untuk memproduksi minyak VCO sesuai standar kualitas yang diinginkan.

Virgin coconut oil ( $\mathrm{VCO})$ merupakan minyak yang diperoleh dari pengolahan daging buah kelapa yang segar dan berasal dari kelapa yang tua, diproses dengan cara mekanis dan secara alami, dengan tanpa atau menggunakan panas, sehingga tidak menyebabkan perubahan kandungan pada minyak. Kegunaan VCO adalah untuk keperluan pangan seperti minyak goreng, bahan margarin, dan mentega putih. Asy'ari dan Cahyono (2006) menyatakan bahwa VCO mempunyai struktur kimia asam lemak jenuh yang tidak memiliki double bond, VCO relatif tahan terhadap panas, cahaya, dan oksigen single sehingga memiliki daya simpan lama. Sebih lanjut dinyatakan bahwa VCO bermanfaat bagi kesehatan dengan mengkonsumsi secara langsung ataupun dapat digunakan untuk menggoreng atau menumis makanan.

Badan Usaha Milik Desa (BUMDes) adalah lembaga usaha desa yang dikelola oleh masyarakat dan pemerintahan desa dalam upaya memperkuat perekonomian desa dan dibentuk berdasarkan kebutuhan dan potensi desa. BUMDes desa Dalang dan Gadung sari telah terbentuk dengan mengelola usaha khususnya dalam hal memproduksi VCO. Kendala utama yang dihadapi dalam memproduksi VCO adalah pemasaran hasil yang kurang sehingga terdapat stok yang banyak yang dikuatirkan akan menjadi tengik. Untuk mengatasi hal tersebut dicoba untuk mencari solusi yaitu dengan memproduksi turunan dari VCO yaitu sabun, lulur scrubb beras dan hand body lotion.

Berdasarkan uraian tersebut diatas, pengabdian kepada masyarakat ini bertujuan untuk mendampingi BUMDes di desa Dalang dan Gadung Sari Kecamatan Selemadeg Timur, Kabupaten Tabanan Bali dalam memproduksi VCO dan turunannya beserta peluang untuk pemasaran produk tersebut. Dengan harapan bahwa produk BUMDes akan meningkat yang akhirnya dapat meningkatkan pendapatan masyarakat.

\section{METODE PELAKSANAAN}

\subsection{METODE}

Metode yang diterapkan dalam pemberdayaan masyarakat pada kegiatan PKW ini adalah sebagai berikut: (1) Penyuluhan untuk membangun persepsi dan pemahaman masyarakat khususnya Kelompok Tani di desa Dalang dan Gadung Sari mengenai inovasi atau program pembuatan VCO dan turunannya yang diterapkan, (2) Pelatihan mengenai terapan ipeks pembuatan turunan VCO yang diaplikasi bagi anggota Kelompok Tani, dan (3) Pendampingan yaitu pertemuan secara berkala dan berkelanjutan antara pendamping dengan anggota Kelompok Tani 
Pengembangan Badan Usaha Milik Desa (BUMDes) Melalui Produksi Virgin Coconut Oil dan Turunannya di Desa Dalang dan Gadung Sari

sasaran hingga ipteks pembuatan VCO dan turunannya yang diaplikasikan dapat dilaksanakan secara tepat oleh angota Kelompok Tani yang tergabung didalam BUMDes. Data produksi, pemasaran dan analisis ekonomi VCO dan turunannya dijabarkan secara deskriptif

\subsection{TAHAPAN KEGIATAN} berikut:

Pelaksananan kegiatan alih teknologi dalam memproduksi VCO dan turunannya sebagai

(1) Kordinasi dan komunikasi secara partisipasif dengan anggota Kelompok untuk merumuskan program mulai dari perencanaan, operasional dan evaluasi.

(2) Penyuluhan tentang pentingnya memproduksi VCO dan turunannya

(3) Pelatihan pengolahan pembuatan VCO dan turunannya.

(4) Proses pembuatan VCO adalah dengan metode tradisional sebagai berikut:

Kelapa diparut, kemudian diperas hingga menghasilkan santan. Santan yang diperoleh ditempatkan pada wadah yang bersih, steril dan transparan lalu didiamkan selama 1 jam hingga terbentuk krim santan. Pisahkan krim santan dari pelarut airnya dan tempatkan krim santan dalam wadah bertutup yang bersih, steril dan transparan. Kemudian diamkan selama 10-12 jam dalam kondisi wadah tertutup dan tempat yang kering. Pisahkan minyak VCO dari krim santan dengan metode penyedotan dengan selang kecil. VCO yang diperoleh disaring dengan menggunakan kertas saring yang bersih dan steril.

(5) Proses pembuatan sabun, lulur scrubb beras dan hand body lotion mengacu pada prosedur pembuatan sabun padat transparan, lulur scrubb beras dan hand body lotion dari Duraposita Chemicka (Perum Korpri, Popongan Karanganyar, Jateng).

\section{HASIL DAN PEMBAHASAN}

Hasil pendampingan pembuatan VCO di desa Dalang dan Gadung Sari Kecamatan Selemadeg Timur Kabupaten Tabanan Bali menunjukkan bahwa untuk memproduksi satu liter VCO dibutuhkan kelapa antara 10-15 butir (Ardika dan Darmiati, 2018). Hal ini mengindikasikan bahwa ada pengaruh jumlah kelapa untuk menghasilkan VCO. Syarat-syarat kelapa untuk dijadikan VCO antara lain: 1) kulit kelapa berwarna coklat menandakan kelapa sudah cukup tua, 2) apabila dikocok berbunyi nyaring yang menandakan bahwa air kelapa sudah berkurang, hal ini bekaitan dengan dekomposisi kandungan gizi kelapa, 3) kelapa belum berkecambah, 4) bila dibelah, daging buah berwarna putih dengan ketebalan sekitar 10-15 mm, 5) umur pohon kelapa tidak terlalu muda atau terlalu tua. Disamping jumlah kelapa, faktor anggota kelompok juga nampaknya berpengaruh terhadap hasil produksi VCO. VCO di KWT. Nadi Sari Desa Dalang dibuat secara tradisional, sudah barang tentu tergantung juga dari proses produksi yakni proses pemerasan kelapa menjadi santan. Santan yang diperoleh tergantung dari kekuatan pemerasan dari ibu-ibu KWT, disamping pengalaman juga berpengaruh. sedangkan pada BUMDes desa Gadung Sari sudah memakai peralatan listrik.

Kualitas VCO sesuai dengan hasil uji laboratorium menunjukkan bahwa kadar asam laurat di dua desa sudah memenuhi standar APCC., yaitu sebesar 40,01\% di desa Gadung Sari dan 49,82\% di desa Dalang. Menurut Asy'ari dan Cahyono (2006) asam laurat termasuk dalam golongan asam lemak rantai jenuh terutama yang berantai pendek sampai sedang (seperti asam laurat) disinyalir akan meningkatkan kualitas dari minyak VCO. Hal ini berkaitan dengan semakin mudahnya jenis asam lemak tersebut untuk ditransper di dalam darah dan akan segera diubah menjadi energi setelah masuk ke dalam sel. Sehingga kandungan asam tersebut yang tinggi di dalam minyak VCO akan meningkatkan kualitas terutama berkaitan dengan sumber energi dan meningkatkan vitalitas bagi tubuh, asam oleat dan asam linoleat memang terbukti mampu menurunkan kadar kolesterol tubuh. 
Produk VCO dan sabun pada BUMDes Desa Gadung Sari (Gambar 1) dipasarkan kepada masyarakat disekitar dan mendapatkan orderan dari Perusahaan Daerah Dharma Santhika Kabupaten Tabanan. Perusahaan daerah setiap bulan membeli produk sabun BUMDes Gadung Sari sebanyak 80 paket, setiap paket berisi empat biji sabun. Produk BUMDes berupa sabun ini diperuntukkan kepada Pegawai Negeri Sipil dilingkungan Pemerintah Daerah Kabupaten Tabanan.

Kelompok Wanita Tani Nadi Sari Banjar Kulkul Batu, Desa Dalang telah memproduksi VCO dan turunannya seperti sabun padat transparan juga memproduksi lulur scrubb beras dan handbody lotion. Pemasarannya, disamping mendapatkan pesanan dari Perusahaan Daerah Kabupaten Tabanan, KWT. Nadi Sari juga sangat aktif memasarkan produknya (Gambar 2). Saluran distribusi pemasaran hasil dari KWT. Nadi Sari berupa produsen-konsumen, produsen-pengecer konsumen, dan produsen-agen tunggal-pengecer-konsumen. Fadini (2017) menyatakan bahwa produsen memiliki sumber daya keuangan, manajerial, dan pemasaran yang besar lebih baik mengunakan saluran langsung, sedangkan perusahaan yang kecil dan lemah lebih baik menggunakan jasa perantara.

Merujuk pada hasil penjualan kelompok mitra dapat dilihat bahwa produk yang terbanyak dibeli oleh konsumen adalah VCO, diikuti dengan lulur scrubb beras dan handbody lotion masing-masing 258 botol, 133 buah, 125 biji, dan 84 buah. Analisis ekonomi sederhana berdasarkan hasil wawancara dengan pegawai BUMDes Desa Gadung Sari menyatakan bahwa untuk memproduksi satu biji sabun memerlukan biaya sebesar Rp. 4.200, selanjutnya satu biji sabun dijual seharga Rp. 5.000 per biji. Dengan demikian dapat dinyatakan bahwa untuk memproduksi satu biji sabun mendapatkan keuntungan sebesar Rp. 800. Biaya produksi sabun padat transparan, lulur scrubb beras dan handbody lotion produksi KWT Nadi Sari Banjar Kulkul Batu Desa Dalang masingmasing sebesar Rp.8.174, Rp. 6.500, dan Rp. 6.500. Produk yang bersangkutan dijual dengan harga masing-masing sebesar Rp. 10.000. Dengan demikian produksi sabun, lulur scrubb beras dan handbody lotion pada kedua desa sangat menjanjikan, mengingat keuntungan yang diperoleh cukup sehingga dapat meningkatkan pendapatan masyarakat.

Namun demikian, menurut Sardiana, dkk (2015) pengembangan sebuah usaha tidak terbatas pada pendampingan teknis perbaikan kualitas produk saja, melainkan juga perlu diberikan pendampingan tentang keterampilan manajerial dan pemasaran. Pemanfaatan teknologi informasi melalui pembuatan website dan pemasaran secara online juga sangat penting dilakukan untuk meningkatkan pendapatan usaha.

\section{KESIMPULAN DAN SARAN}

Dari uraian diatas dapat disimpulkan bahwa: (1) BUMDes berperanan penting dalam memajukan perekonomian masyarakat di desa Dalang dan Gadung Sari Kecamatan Selemadeg Timur Kabupaten Tabanan; (2) Produksi VCO beserta turunannya (sabun, lulur scrubb beras dan handbody lotion) memiliki prospek yang cukup menjanjikan yang dapat menambah penghasilan masyarakat, khususnya ibuk-ibuk rumah tangga.

Disarankan untuk kelompok wanita tani baik di desa Gadung Sari dan Dalang secara terus menerus untuk memproduksi VCO dan turunannya untuk dapat meningkatkan pendapatan KWT. maupun BUMDes.

\section{UCAPAN TERIMAKASIH}

Penulis menyampaikan terima kasih yang sebesar-besarnya kepada Direktorat Riset dan Pengabdian Kepada Masyarakat Direktorat Jenderal Penguatan dan Pengembangan Kementerian Riset, Teknologi dan Pendidikan Tinggi sehigga pengabdian ini dapat terlaksana, Ketua Lembaga Pengabdian kepada Masyarakat 
Pengembangan Badan Usaha Milik Desa (BUMDes) Melalui Produksi Virgin Coconut Oil dan Turunannya di Desa Dalang dan Gadung Sari

Universitas Udayana, Bappeda Kabupaten Tabanan, serta seluruh masyarakat yang telah membantu kelancaran kegiatan ini.

\section{DAFTAR PUSTAKA}

Ardika, I N. dan N. N. Darmiati, 2018. Produksi dan kualitas Virgin Coconut Oil (VCO) di Desa Dalang dan Gadung Sari Kecamatan Selemadeg Timur Kabupaten Tabanan, Bali. Bulletin Udayana Mengabdi 17(3):77-82.

Asy,ari, M. dan B. Cahyono. 2006. Pra standarisasi produksi dan virgin coconut oil. JSKA. IX (3): 1-9.

Fadini. A. 2017. Strategi pemasaran. https://amaliafadini.wordpress.com/2017/07/27/makalah strategi pemasaran. Diakses tanggal 5 September 2018.

Pontoh, J. M., Br. Surbakti dan M. Papilaya. 2008. Kualitas virgin coconut oil dari beberapa metode pembuatan. Chem. Prog. 1(1):60-65.

Sardiana, I.K., B.R.T. Putri, I.G. Suranjaya, N.L.R. Purnawan. 2015. Pengembangan Kewirausahaan Di Universitas Udayana. Majalah Aplikasi Ipteks Ngayah : Vol. 6, No. 1, pp. 91-101.
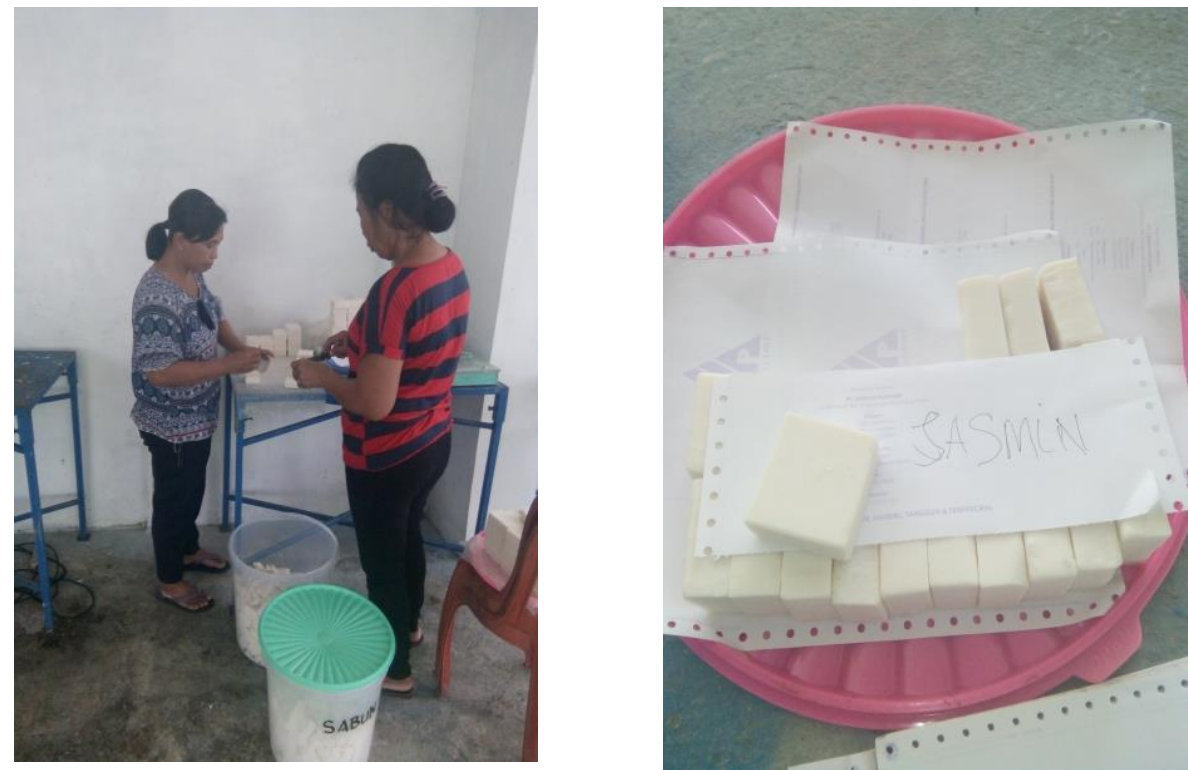

Gambar 1. Produksi Sabun pada BUMDes Desa Gadung Sari
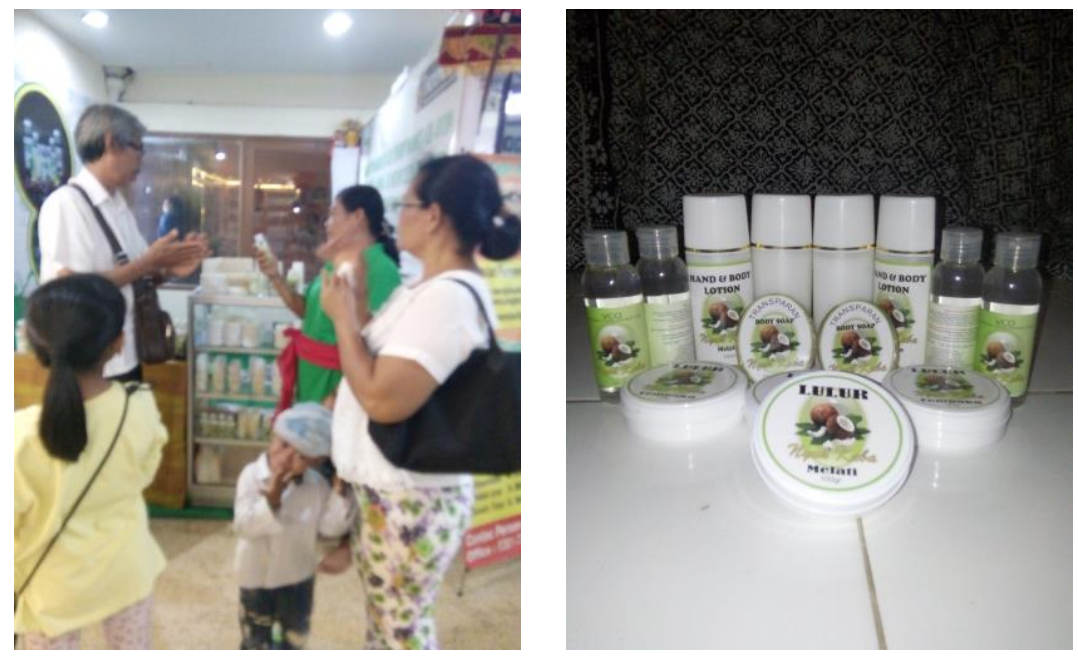

20 | BULETIN UDAYANA MENGABDI 
I N. Ardika, N.N. Darmiati dan I N. Sujana

Gambar 2. Pemasaran Produk KWT. Nadi Sari pada PKB Denpasar 